\title{
Brazilian donkeys (Equus asinus) have a low exposure to Neospora spp.
}

\author{
Asininos (Equus asinus) brasileiros têm uma baixa exposição à Neospora spp. \\ Cynthia Maria Morais de Queiroz Galvão ${ }^{1}$; Mariana Marrega Rezende-Gondim ${ }^{1}$; Ana Carla Rodrigues Chaves $^{1}$; \\ Gereon Schares²; Jorge Raimundo Lins Ribas³; Luís Fernando Pita Gondim*

\begin{abstract}
${ }^{1}$ Departamento de Anatomia, Patologia e Clínicas, Escola de Medicina Veterinária e Zootecnia, Universidade Federal da Bahia UFBA, Salvador, BA, Brasil

${ }^{2}$ Friedrich-Loeffler-Institut - FLI, Federal Research Institute for Animal Health, Institute of Epidemiology, Südufer, Greifswald-Insel Riems, Germany
\end{abstract} \\ ${ }^{3}$ Agência Estadual de Defesa Agropecuária da Bahia - ADAB, Salvador, BA, Brasil
}

Received May 6, 2015

Accepted June 1, 2015

\begin{abstract}
Donkeys (Equus asinus) are closely related to horses and are known to be infected by several equine pathogens. Neospora caninum and Neospora hughesi are protozoan parasites that infect horses, but they were not confirmed in donkeys up to this date. The aim of this study was to evaluate the exposure of donkeys (Equus asinus) to Neospora spp. using tachyzoites of $N$. caninum as antigen and employing two common serologic methods, IFAT and immunoblot. Sera from 500 donkeys were obtained from 30 municipalities in Bahia state and tested by IFAT. Two of 500 sera were positive for Neospora spp. by IFAT with antibody titers of 100 , and recognized a $37 \mathrm{kDa}$ antigen in immunoblot. Approximately $22 \%$ of the samples showed strong apical reactions and/or incomplete fluorescence, what may cause confusion in the interpretation of IFAT. We concluded that Neospora spp. are possibly of minor importance for Brazilian donkeys. Future studies are necessary to prove that Neospora spp. can naturally infect donkeys.
\end{abstract}

Keywords: Neospora, Equus asinus, donkeys, antibodies.

\section{Resumo}

Asininos (Equus asinus) são próximos filogeneticamente a equinos e podem ser infectados por vários patógenos de cavalos. Neospora caninum e Neospora hughesi são parasitos protozoários que infectam equinos, porém não foram confirmados em asininos até o momento. O objetivo deste estudo foi avaliar a exposição de asininos (Equus asinus) a Neospora spp., usando-se taquizoítos de $N$. caninum como antígeno e empregando-se duas técnicas sorológicas comuns para esta finalidade, reação de imunofluorescência indireta (RIFI) e immunoblot. Soros de 500 asininos, obtidos em 30 municípios no Estado da Bahia, foram testados por meio da RIFI. Dois dos 500 soros foram positivos para Neospora spp. pela RIFI com títulos de anticorpos de 100 , e reconheceram um antígeno de $37 \mathrm{kDa}$ no immunoblot. Aproximadamente, $22 \%$ das amostras apresentaram fortes reaçôes apicais e/ou fluorescência incompleta, o que pode causar confusão na interpretação da RIFI. Conclui-se que Neospora spp. são, possivelmente, de pouca importância para asininos brasileiros. Estudos posteriores são necessários para provar que Neospora spp. podem causar infecção natural em asininos.

Palavras-chave: Neospora, Equus asinus, asininos, anticorpos.

\section{Introduction}

Neospora caninum is a protozoan parasite that causes a great economic impact in cattle industry worldwide (REICHEL et al., 2013). The parasite is commonly transmitted to herbivores via transplacental infection or through ingestion

*Corresponding author: Luís Fernando Pita Gondim. Departamento de Anatomia, Escola de Medicina Veterinária e Zootecnia, Patologia e Clínicas, Universidade Federal da Bahia - UFBA, Av. Adhemar de Barros, 500, Ondina, CEP 40170-110, Salvador, BA, Brasil. e-mail: pita@ufba.br of oocysts shed in the feces from definitive hosts (DH). There are four canid species identified as DH of $N$. caninum, which are domestic dogs (MCALLISTER et al., 1998), coyotes (GONDIM et al., 2004), Australian dingoes (KING et al., 2010) and grey wolves (DUBEY et al., 2011). A great number of mammalian species, including horses, may serve as intermediate hosts for $N$. caninum. Some of these hosts may present neosporosis (GOODSWEN et al., 2013). 
A second species was proposed in the genus Neospora (N. hughesi), isolated from a horse with neurological disease. Its classification was based on molecular, antigenic and ultrastructural differences from N. caninum (MARSH et al., 1998). Therefore, the equine protozoal mieloencephalitis (EPM), a serious neurologic disease of horses, which had Sarcocystis neurona as its sole agent (DUBEY et al., 1991), was shown to have Neospora hughesi ( $N$. hughesi) as a second etiologic agent. Walsh et al. (2000) tested whether dogs could serve as definitive hosts for $N$. hughesi. Two dogs were fed brains from $N$. hughesi-experimentally infected mice. The dogs did not excrete Neospora-like oocysts in their feces. These authors concluded that dogs do not appear to be definitive hosts of the parasite. So far, no animal has been identified as DH of $N$. hughesi.

Horses are infected by both $N$. caninum and $N$. hughesi. The former may cause abortion in horses and the latter was only associated with neurologic disease in this animal species (MARSH et al., 1998; PITEL et al., 2003). However, no serologic test has been proved to differentiate infections caused by $N$. caninum and $N$. hughesi (GONDIM et al., 2009).

Donkeys (Equus asinus) are closely related to horses and are affected by several microorganisms that are commonly found in equines, including the protozoa Theileria equi and Babesia caballi (MACHADO et al., 2012). In two publications, donkeys from Italy and Iran were reported to be exposed to Nespora spp. based on the detection of anti-Neospora sp. antibodies (GHAREKHANI et al., 2013; MACHAČOVÁ et al., 2013). In each of these reports, a single serologic method was used to test the animal sera. Up to this date, there is no confirmation of Neospora DNA or detection of any Neospora stages (tachyzoites or encysted bradzyoites) in tissues from donkeys.

The aim of this study was to test whether donkeys raised in Bahia state, Brazil, are exposed to Neospora sp. through two serologic tests.

\section{Materials and Methods}

\section{Animals}

The sample size for this study was calculated according to the reported population of donkeys (271.401) in Bahia state, (Brazilian Agency of Geography and Statistics - IBGE (2010). At the time the experiment was planned, no epidemiological data were available for Neospora sp. in donkeys. Therefore, an expected frequency for Neospora spp. antibodies in horses (2.5\%) (HOANE et al., 2006) was used for the sample size estimation. A confidence interval of $95 \%$ and precision of $5 \%$ were used in the sample calculation. Values of $\mathrm{p}<0.05$ were considered significant.

Bahia state has a country-like territorial extension $\left(564,733,177 \mathrm{~km}^{2}\right)$ which is larger than countries such as France and Germany. It possesses the largest population of donkeys in Brazil, corresponding to 271.401 animals (IBGE, 2010).

A total of 500 sera from donkeys were obtained between the years of 2009 and 2012. The animals were originated from 30 municipalities distributed in the state of Bahia (Figure 1). Most animals (275) were 5 to 10 years old, 159 were below 5 years old, and 66 animals had ages above 10 years. Males and females

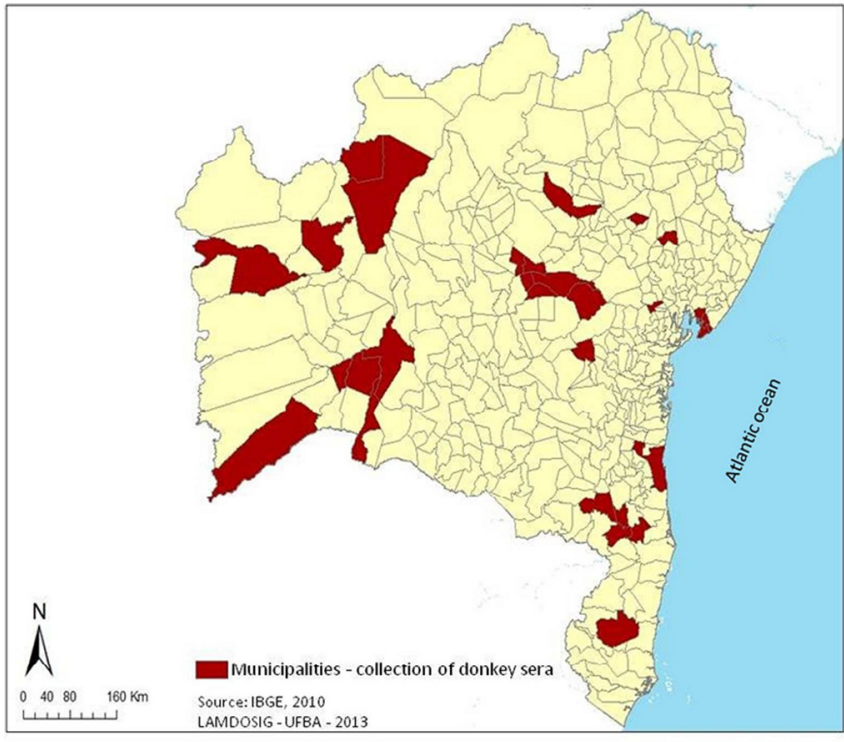

$160 \times 140 \mathrm{~mm}(300 \times 300 \mathrm{DPI})$

Figure 1. Serum samples from donkeys were obtained in 30 municipalities in Bahia state, Brazil, during the years of 2009 and 2012.

corresponded to 191 and 309 donkeys, respectively. Sera from 173 animals were obtained in a donkey breeding farm in the municipality of Valente, Bahia, which sells donkeys for several regions in Bahia and to other Brazilian states, mainly for the production of hybrids (mules). The remaining sera (327 samples) were originated from 29 municipalities.

\section{Cell culture and antigen preparation for IFAT}

Tachyzoites of $N$. caninum (NC-Bahia strain) were used as antigen for IFAT reactions. The parasites were maintained in monolayers of VERO cells, cultured with RPMI-1650 + L-glutamin (Invitrogen/Gibco ${ }^{\circledR}$, New York, USA), supplemented with antibiotic-antimycotic: 100 units $/ \mathrm{mL}$ of penicillin, $100 \mu \mathrm{g} / \mathrm{mL}$ of streptomycin and $0.25 \mu \mathrm{g} / \mathrm{mL}$ of Fungizone ${ }^{\circledR}$-amphotericin B $\left(\right.$ Gibco $\left.^{\circledR}, \mathrm{USA}\right), 10 \%$ of inactivate calf serum (Invitrogen/Gibco ${ }^{\circledR}$, Auck-land, NZ) at $37^{\circ} \mathrm{C}$ in $5 \% \mathrm{CO}_{2}$. Tachyzoites were harvested with a cell scraper when approximately $2 / 3$ of cell mono-layer was disrupted by the parasites. The harvested suspensions were centrifuged at $1000 \times g$ for $10 \mathrm{~min}$ at $4{ }^{\circ} \mathrm{C}$, resuspended in filtered phosphate buffered saline (PBS) pH 7.2, passed through a 22-Gauge needle and purified using a $5 \mu$-syringe filter. The filtered zoites were washed three times with sterile PBS ( $\mathrm{pH} 7.2$ ), placed in $5 \mathrm{~mm}$-well slides, and fixed by methanol for $5 \mathrm{~min}$. The slides were stored at $-20{ }^{\circ} \mathrm{C}$ no more than 2 months until used.

Indirect immunofluorescence antibody test (IFAT)

The samples were analyzed in a second time by a different person. The number of sera included in the analysis was 499, because one of the 500 samples was in small amount and in insufficient for other tests. At this time, NC-1 tachyzoites were used as antigens and the samples were examined according to methods described 
by Schares et al. (1999). Positive and negative controls from a $N$. caninum-positive bovine were used in each antigen slide.

\section{D SDS PAGE and immunoblot using N. caninum antigen}

Tachyzoites of the $N$. caninum strain NC-1 (DUBEY et al., 1988) were cultured similarly as described above, but Marc-145 was employed as host cells with DMEM as culture medium. The parasites were separated from the host cells using $5 \mu \mathrm{m}$ filter and pelleted by centrifugation. A pellet containing $4.8 \times 10^{8}$ tachyzoites was used for antigen preparation. The SDS PAGE and immunoblot were performed according to Schares et al. (1998). The parasites were mixed with a sample buffer (2\% SDS, 10\% glycerol, $62 \mathrm{mM}$ Tris $\mathrm{HCl}, \mathrm{pH}$ 6.8), heated at $97^{\circ} \mathrm{C}$ for $10 \mathrm{~min}$, and centrifuged for $13,000 \mathrm{~g}$ for $10 \mathrm{~min}$ at $4^{\circ} \mathrm{C}$. The supernatant containing antigen and a protein marker were run on a SDS-polyacrilamide gel $(12.5 \%)$ and transferred to a Polyvinylidene difluoride (PVDF) membrane. The membrane was blocked with PBS Tween (PBS-T) (0.05\% Tween 20) containing 2\% of gelatin (PBS-T-Gelatin), and cut in stripes of approximately $2 \mathrm{~mm}$ of width.

The donkey sera (499 samples) were diluted 1:100 and incubated with the antigen stripes at room temperature under agitation for $1 \mathrm{~h}$. Positive and negative controls from bovine were included in each analysis at 1:500 dilutions. The membranes were washed 5 times in PBS-T, and a peroxidase conjugate anti-donkey IgG in PBS-T-Gelatin was added to the reactions. A peroxidase anti-bovine IgG conjugate was employed for the bovine sera. The membranes were incubated for $1 \mathrm{~h}$, washed 3 times with PBS-T, 3 times with PBS, then incubated with 4-Chloro-1-naftol in methanol $\left(1: 4\right.$ in PBS with $\left.0.1 \% \mathrm{H}_{2} \mathrm{O}_{2}\right)$ as substrate. When the reactive bands were clearly seen, the reactions were stopped by adding water into the wells.

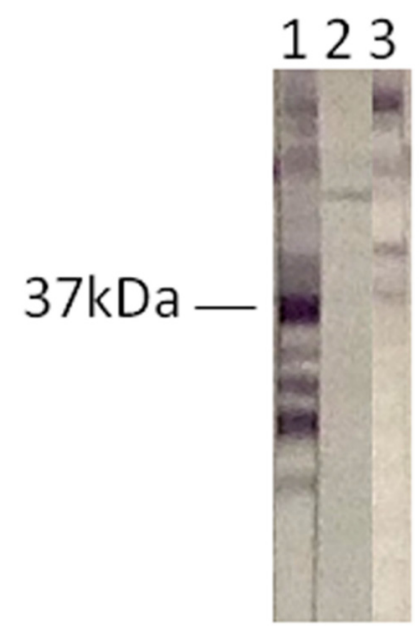

Figure 2. Immunoblot using serum from a Neospora caninum-infected bovine (1), a negative control serum from bovine (2), and serum from a donkey which tested positive by IFAT for Neospora spp. with an antibody titer of 100 (3). Note the weak positive reaction of a band at approximately $37 \mathrm{kDa}$.

\section{Results}

Antibodies against Neospora spp. were initially detected by IFAT in $21.6 \%(108 / 500)$ of the donkeys. A second analysis was performed by a second veterinarian who noted that most positive reactions were in fact strong apical reactions and/or incomplete fluorescence around the surface of the tachyzoites. The number of true positive samples in the second analysis was $2 / 500(0.4 \%)$. These reactions were characterized by complete fluorescence in the periphery of the tachyzoites. Both reactive samples had antibody titers of 100 .

Immunoblot using non-reduced antigen of $N$. caninum was performed in all samples from donkeys. The two reactive samples observed by IFAT showed reactions against a $37 \mathrm{kDa}$ antigen (Figure 2).

\section{Discussion}

In the current study, we tested the exposure of 500 donkeys to Neospora spp. Donkeys are closely related to horses and may be potentially infected by $N$. caninum and $N$. hughesi, which cause disease in horses (MARSH et al., 1998; PITEL et al., 2003). The donkey sera were analyzed by IFAT and immunoblot. Donkeys exhibited a low frequency of antibodies against Neospora sp. by IFAT. When tested by immunoblot using non-reduced antigen from $N$. caninum, two serum samples reacted against a $37 \mathrm{kDa}$ antigen.

It is important to note that $21.6 \%$ of the samples in the initial analysis were incorrectly interpreted as positive by IFAT. The examination of the tested sera by a second veterinarian revealed that most reactions assumed as positive in the first analysis were in fact apical and/or incomplete reactions, what caused confusion in the classification of the positive results. After immunoblot, two sera with IFAT titers of 100 recognized a $37 \mathrm{kDa}$ antigen, regarded as one of the immunodominant antigens of $N$. caninum (BARTA \& DUBEY, 1992).

Neospora caninum is spread in cattle in Bahia state and has also been isolated from a naturally-infected dog in the same region (GONDIM et al., 2001; GONDIM et al., 1999). In the current study, the low frequency of antibodies observed in donkeys bred in Bahia, where dogs are commonly raised close to donkeys, is suggestive that Neospora spp. are of minor importance for this animal species. In a study performed in Italy, $11.8 \%$ of 238 donkeys were positive for Neospora spp. using a commercial competitive-inhibition ELISA (cELISA, VMRD, Inc., Pullman, WA, USA) for $N$. caninum (MACHAČOVÁ et al., 2013). In another study conducted in Iran, 100 sera from donkeys were tested by a Neospora modified agglutination test (N-MAT) and revealed 52\% of reactive samples. Despite both techniques (cELISA and N-MAT) that were employed in the studies from Italy and Iran have been tested using other animal species (reviewed by BJORKMAN \& UGGLA, 1999), they had not been tested before with sera from donkeys. It is uncertain whether the positive reactions truly represent exposure to Neospora spp. or are due to potential cross-reactivity to other cyst-forming coccidian from donkeys.

In the present work, the combination of IFAT and immunoblot using antigens derived from $N$. caninum tachyzoites is suggestive 
that only two of the 500 tested Brazilian donkeys were exposed to Neospora spp. However, Neospora spp. have never been reported in donkeys and the putative detection of antibodies to Neospora spp. in our study does not prove that the animals were infected by the parasites.

Four immunodominant antigens have been identified in immunoblot for $N$. caninum $(16 / 17,29,37$ and $46 \mathrm{kDa})$ using non-reduced antigen from tachyzoites (BARTA \& DUBEY, 1992). Sondgen et al. (2001) performed immunoblot using fetal fluids from aborted bovine fetuses and non-reduced antigen from $N$. caninum tachyzoites. These authors observed that the $37 \mathrm{kDa}$, followed by the $29 \mathrm{kDa}$ antigens were the most frequently identified antigens by Neospora-positive animals.

We conclude that, up to this date, there is no strong serologic evidence that Neospora spp. is able to infect donkeys. We used a quite large sample size and two serologic techniques, but only two animals were reactive with low antibody titers by IFAT. In addition, their sera recognized only one $N$. caninum immunodominant antigen of $37 \mathrm{kDa}$ by immunoblot. Further studies are necessary to confirm whether $N$. caninum and $N$. hughesi are able to infect donkeys.

\section{Acknowledgements}

This study was supported by Conselho Nacional de Desenvolvimento Científico e Tecnológico (CNPq) from Brazil, and partially granted by funds from the Alexander von Humboldt Foundation, Germany. We thank to Müller R. Andrade and Rogério F. Jesus for excellent technical assistance. We are thankful to Marta M. Nascimento for helping with the geographical data.

\section{References}

Barta JR, Dubey JP. Characterization of anti-Neospora caninum hyperimmune rabbit serum by western blot analysis and immunoelectron microscopy. Parasitol Res 1992; 78(8): 689-694. http://dx.doi.org/10.1007/ BF00931522. PMid:1480607.

Björkman C, Uggla A. Serological diagnosis of Neospora caninum infection. Int J Parasitol 1999; 29(10): 1497-1507. http://dx.doi.org/10.1016/ S0020-7519(99)00115-0. PMid:10608435.

Dubey JP, Davis SW, Speer CA, Bowman DD, Lahunta A, Granstrom DE, et al. Sarcocystis neurona n. sp. (Protozoa: Apicomplexa), the etiologic agent of equine protozoal myeloencephalitis. J Parasitol 1991; 77(2): 212-218. http://dx.doi.org/10.2307/3283084. PMid:1901359.

Dubey JP, Hattel AL, Lindsay DS, Topper MJ. Neonatal Neospora caninum infection in dogs: isolation of the causative agent and experimental transmission. J Am Vet Med Assoc 1988; 193(10): 1259-1263. PMid:3144521.

Dubey JP, Jenkins MC, Rajendran C, Miska K, Ferreira LR, Martins J, et al. Gray wolf (Canis lupus) is a natural definitive host for Neospora caninum. Vet Parasitol 2011; 181(2-4): 382-387. http://dx.doi.org/10.1016/j. vetpar.2011.05.018. PMid:21640485.

Gharekhani J, Tavoosidana G-R, Naderisefat G-R. Seroprevalence of Neospora infection in horses and donkeys in Hamedan province,
Western Iran. Vet World 2013; 6(9): 620-622. http://dx.doi.org/10.5455/ vetworld.2013.620-622.

Gondim LF, Lindsay DS, McAllister MM. Canine and bovine Neospora caninum control sera examined for cross-reactivity using Neospora caninum and Neospora hughesi indirect fluorescent antibody tests. J Parasitol 2009; 95(1): 86-88. http://dx.doi.org/10.1645/GE-1710.1. PMid:18613752.

Gondim LF, Pinheiro AM, Santos PO, Jesus EE, Ribeiro MB, Fernandes HS, et al. Isolation of Neospora caninum from the brain of a naturally infected dog, and production of encysted bradyzoites in gerbils. Vet Parasitol 2001; 101(1): 1-7. http://dx.doi.org/10.1016/S0304-4017(01)00493-9. PMid:11587828.

Gondim LFP, McAllister MM, Pitt WC, Zemlicka DE. Coyotes (Canis latrans) are definitive hosts of Neospora caninum. Int J Parasitol 2004; 34(2): 159-161. http://dx.doi.org/10.1016/j.ijpara.2004.01.001. PMid:15037103.

Gondim LFP, Sartor IF, Hasegawa M, Yamane I. Seroprevalence of Neospora caninum in dairy cattle in Bahia, Brazil. Vet Parasitol 1999; 86(1): 71-75. http://dx.doi.org/10.1016/S0304-4017(99)00129-6. PMid:10489205.

Goodswen SJ, Kennedy PJ, Ellis JT. A review of the infection, genetics, and evolution of Neospora caninum: from the past to the present. Infect Genet Evol2013; 13: 133-150. http://dx.doi.org/10.1016/j.meegid.2012.08.012. PMid:22985682.

Hoane JS, Gennari SM, Dubey JP, Ribeiro MG, Borges AS, Yai LE, et al. Prevalence of Sarcocystis neurona and Neospora spp. infection in horses from Brazil based on presence of serum antibodies to parasite surface antigen. Vet Parasitol2006; 136(2): 155-159. http://dx.doi.org/10.1016/j. vetpar.2005.10.023. PMid:16310955.

Instituto Brasileiro de Geografia e Estatística - IBGE. Produção da pecuária municipal. Rio de Janeiro; 2010. p. 1-65. vol. 38.

King JS, Slapeta J, Jenkins DJ, Al-Qassab SE, Ellis JT, Windsor PA. Australian dingoes are definitive hosts of Neospora caninum. Int J Parasitol 2010; 40(8): 945-950. http://dx.doi.org/10.1016/j.ijpara.2010.01.008. PMid:20149793.

Machačová T, Bártová E, Di Loria A, Sedlák K, Guccione J, Fulgione D, et al. Seroprevalence and risk factors of Neospora spp. in donkeys from Southern Italy. Vet Parasitol 2013; 198(1-2): 201-204. http://dx.doi. org/10.1016/j.vetpar.2013.08.013. PMid:24050943.

Machado RZ, Toledo CZP, Teixeira MCA, André MR, Freschi CR, Sampaio PH. Molecular and serological detection of Theileria equi and Babesia caballi in donkeys (Equus asinus) in Brazil. Vet Parasitol 2012; 186(3-4): 461-465. http://dx.doi.org/10.1016/j.vetpar.2011.11.069. PMid:22186194.

Marsh AE, Barr BC, Packham AE, Conrad PA. Description of a new Neospora species (Protozoa: Apicomplexa: Sarcocystidae).J Parasitol 1998; 84(5): 983-991. http://dx.doi.org/10.2307/3284632. PMid:9794642.

McAllister MM, Dubey JP, Lindsay DS, Jolley WR, Wills RA, McGuire AM. Rapid communication: dogs are definitive hosts of Neospora caninum. Int J Parasitol 1998; 28(9): 1473-1478. http://dx.doi.org/10.1016/ S0020-7519(98)00138-6. PMid:9770635.

Pitel PH, Lindsay DS, Caure S, Romand S, Pronost S, Gargala G, et al. Reactivity against Sarcocystis neurona and Neospora by serum antibodies 
in healthy French horses from two farms with previous equine protozoal myeloencephalitis-like cases. Vet Parasitol 2003; 111(1): 1-7. http://dx.doi. org/10.1016/S0304-4017(02)00346-1. PMid:12523974.

Reichel MP, Ayanegui-Alcérreca MA, Gondim LF, Ellis JT. What is the global economic impact of Neospora caninum in cattle: the billion dollar question. Int J Parasitol 2013; 43(2): 133-142. http://dx.doi.org/10.1016/j. ijpara.2012.10.022. PMid:23246675.

Schares G, Peters M, Wurm R, Bärwald A, Conraths FJ. The efficiency of vertical transmission of Neospora caninum in dairy cattle analysed by serological techniques. Vet Parasitol 1998; 80(2): 87-98. http://dx.doi. org/10.1016/S0304-4017(98)00195-2. PMid:9870361.
Schares G, Rauser M, Zimmer K, Peters M, Wurm R, Dubey JP, et al. Serological differences in Neospora caninum-associated epidemic and endemic abortions. J Parasitol 1999; 85(4): 688-694. http://dx.doi. org/10.2307/3285744. PMid:10461950.

Söndgen P, Peters M, Bärwald A, Wurm R, Holling F, Conraths FJ, et al. Bovine neosporosis: immunoblot improves foetal serology. Vet Parasitol 2001; 102(4): 279-290. http://dx.doi.org/10.1016/S0304-4017(01)00543-X. PMid:11731071.

Walsh CP, Duncan RB Jr, Zajac AM, Blagburn BL, Lindsay DS. Neospora hughesi: experimental infections in mice, gerbils, and dogs. Vet Parasitol 2000; 92(2): 119-128. http://dx.doi.org/10.1016/S0304-4017(00)00279-X. PMid:10946135. 